\title{
POLICIES AND PRESSURES FOR DOCTORS IN THE NHS
}

\author{
By R. A. F. Thistlethwaite \\ Chief Press Officer, British Medical Association
}

When Jerome $\mathrm{K}$. Jerome read a medical textbook he decided that he had every illness except housemaid's knee.

The public's interest in medical science, medicine and doctors is insatiable and appears to be still growing. In the BMA Press Office, the national newspapers and major provincials are read and cut every day for medical stories-and every day the result is a heavy bundle of paper. It is simply not practicable to spend the time counting all the column inches on the subject; measurement by weight would be more appropriate.

Each national newspaper employs a full-time correspondent who as a skilled journalist interprets and writes about medical and social services matters. Often a qualified doctor is retained in an advisory capacity. There is a flourishing Medical Journalists' Association with over 200 members, the majority of whom earn most of their living from writing about medicine. With a few honourable exceptions there are not many doctors amongst the leaders in this particular group of popularizers. There are signs that more doctors are overcoming the traditional reticence that may have prevented them from becoming involved in journalism in the past.

\section{Doctors as journalists}

The British Medical Journal runs a number of courses every year designed to help medical authors in the planning and composition of medical articles. For the past two years the Journal has given a one-day seminar for editors of student journals covering the whole range of editorial activities from selecting material and sub-editing copy to the business side.

Doctors who aspire to be journalists are also helped by the existence of a new area where they can develop their journalistic skills while at the same time writing mainly for the profession. A whole new range of independent medical magazines are always keen to consider contributions by doctors. This group of popular medical journals, staffed for the most part by non-medically qualified journalists rather than doctors, is a phenomenon of the last ten years. Pulse, Medical News, General Practitioner and World Medicine are all titles which have become well-known, and there are many more.

These new journals are supported by advertising, mostly from pharmaceutical companies, and are distributed free of charge. The BMA has produced its own version of a popular journal in BMA News Review, a monthly tabloid which is currently enjoying a success despite the obvious problems of beating the weeklies to the news. For the most part the populars owe no particular alliegance to any one group. Because they are highly-profitable publishing enterprises they attract high-powered journalistic staff and are very competitive. This is particularly so in the field of medical politics, where competition has been particularly intense in recent years.

Very few medical bodies open their councils or committees to the press. The British Medical Joumal by tradition summarizes the debates of major BMA Committees and Council in the Supplement so as to keep members informed. Otherwise entry is banned to the press-though BMA members have the right to attend Council. The BMA's Annual Representative Meeting has, of course, been open to the press for as long as anyone can remember, and the annual conferences representing General Practitioners, Consultants, Junior Doctors and Community Physicians were opened to the press some years ago.

A feature of the new medical journalism, as practised by the popular journals, is the close monitoring through contacts in the major committees of what is going on in medical bodies, and particularly the BMA. This can mean that a report of an important debate in Council can appear in a popular medical journal before the definitive summary appears in the British Medical Journal. This shortcutting of lines of communication by the popular journals is intensified when the national press correspondents who read the popular medical journals take up any particularly interesting story. This kind of situation is to be expected when well-financed and enterprising journals with large and expert staffs concentrate on a particular area.

\section{Let them in?}

Such is the pressure for information that the question is bound one day to arise, should those committees and bodies most under siege open their doors to the press? To do so could present logistic and organization problems worthy of an article of their own. In this connection it has been suggested that the medical press alone could be admitted and the national press, television and radio somehow kept out. This simply is not a realistic possibility. Once a press gallery is installed it would not be logical to exclude 
one particular set of journalists. There would also be the reporters for medical journals who were also writing for national newspapers. To provide proper servicing for those reporting committees and for those who might not turn up to report but would require detailed briefing could be a considerable additional expense for any organization running the committees concerned.

\section{The Hothouse}

Never has there been a wider coverage of medical politics. Everything and everybody in the major medical organizations seems to be under minute scrutinynot the meanest piece of gossip is allowed to go unrecorded. This creates something of a hothouse atmosphere for anyone who reads all the popular medical journals and inevitably affects judgement. Considering their influence, it is strange that these journals are distributed to only a section of the medical profession. They are sent to committee members and some leaders of the profession, some hospital doctors, most general practitioners and a few others holding office in medical organizations who need to know what is being said. But their power to influence is not due solely to the fact that they are read by many leading doctors. They have also demonstrated their effectiveness as a platform for those standing in GMC elections.

\section{Many voices}

There have always been pressure groups, but their increasing activity has added fresh complexity to the medical scene. The political nature of the NHS appears to encourage their development. The groups employ press and public relations techniques, the skilled use of Parliamentary questions and careful timing to gain their particular point. So susceptible is the NHS to political influences that such techniques pay off in securing the limited objectives of the groups concerned. The aims of such groups are for the most part entirely praiseworthy, and their activities can be represented as democracy in action, but when in a democracy one side employs public relations techniques surely similar advice is needed for those providing any counter-argument to ensure a fair hearing to both sides. Too often the reasonable argument is lost for lack of orchestration.

Another source of publicity which impinges on all branches of medicine is the large-scale operation of the DHSS. Centrally there is a busy and well-manned press office and a large publicity department. In the Regions there is a comprehensive network of press offices. The industrial unions in the NHS all have their own press offices, as do the political parties who have their own decided views on medicine and what the electorate requires of doctors. Against this background it is not surprising that more and more medical organizations are seeking advice on communications to ensure that their policies are properly presented to the public.

\section{BMA Press Information Department}

The BMA has been running a press office in its present form for thirty years. The job of the department is to provide information and BMA comment on every medical subject with which the BMA is involved. This covers most aspects of medicine. In addition to information about the many BMA committees and study groups and policy decisions the press office can help journalists by providing essential background information for research purposes based on articles in the British Medical Journal and other publications. This comprehensive information service provides the basis for a continuous dialogue with Fleet Street, radio and television journalists and enables the BMA to keep contact with opinion and to transmit its own views speedily to those people who are most interested in medicine and who write for the media. The BMA has provided what has virtually been a press office for medicine as a whole. The BMA press office has always offered help and advice to members wishing to hold a press conference or make an announcement.

But, with the increasing battle to make one's point publicly, a number of medical organizations have engaged advisors on a continuous basis rather than for a single report or event. This is evidence of concern in the profession over the effect of some press, radio and television publicity on patients. The reports in the British Medical Journal carrying detailed criticism of articles and programmes are perhaps another sign of this.

There are from time to time attempts by doctors and journalists to discuss how to reconcile varying attitudes. A recent two-day meeting arranged by the Medical Journalists' Association involving some leading doctors and journalists resulted in a much greater measure of understanding amongst the individuals concerned. Whether the aims of the two professions could ever be reconciled in a mutually acceptable code of practice is doubtful, but there is room for greater understanding and restraint.

The fact that more people seem to be acknowledging the need to learn about the ways in which journalists operate and to learn how best to communicate is in itself encouraging. 